Article

\title{
Formation Mechanism of Spherical TiC in Ni-Ti-C System during Combustion Synthesis
}

\author{
Guoliang Zhu ${ }^{1,2}$, Wei Wang 1,2, Rui Wang ${ }^{1,2}$, Chuanbao Zhao 1,2, Weitao Pan ${ }^{2}$, \\ Haijun Huang ${ }^{1,2}$, Dafan Du ${ }^{1,2}$, Donghong Wang ${ }^{1,2}$, Da Shu ${ }^{1,2, *}$, Anping Dong ${ }^{1,2, *}$, \\ Baode Sun ${ }^{1,2,3,4}$, Sheng Jiang ${ }^{5}$ and Yilong $\mathrm{Pu}^{5}$ \\ 1 Shanghai Key Lab of Advanced High-Temperature Materials and Precision Forming, \\ Shanghai Jiao Tong University, Dongchuan Road 800, Shanghai 200240, China; glzhu@sjtu.edu.cn (G.Z.); \\ wei-1233@163.com (W.W.); wangrui1029@sjtu.edu.cn (R.W.); zhaochuanbao_chris@163.com (C.Z.); \\ cornus@163.com (H.H.); dafand@sjtu.edu.cn (D.D.); wangdh2009@sjtu.edu.cn (D.W.); \\ bdsun@sjtu.edu.cn (B.S.) \\ 2 School of Materials Science and Engineering, Shanghai Jiao Tong University, Dongchuan Road 800, \\ Shanghai 200240, China; panweitao123@126.com \\ 3 State Key Laboratory of Metal Matrix Composites, Shanghai Jiao Tong University, Dongchuan Road 800, \\ Shanghai 200240, China \\ 4 Collaborative Innovation Center for Advanced Ship and Deep-Sea Exploration, \\ Shanghai Jiao Tong University, Dongchuan Road 800, Shanghai 200240, China \\ 5 Jiangsu Longda Superalloy Material Co., Ltd, Wuxi 214105, China; shengjvip@163.com (S.J.); \\ ylongpu@163.com (Y.P.) \\ * Correspondence: dshu@sjtu.edu.cn (D.S.); apdong@sjtu.edu.cn (A.D.); Tel.: +86-21-5474-5597 (A.D.)
}

Received: 26 July 2017; Accepted: 28 August 2017; Published: 29 August 2017

\begin{abstract}
The formation mechanism of $\mathrm{TiC}$ particles in a Ni-Ti-C system were revealed by using differential thermal analysis (DTA), XRD, and SEM to identify the reaction products in different temperature ranges. The results indicated that the synthesis mechanism of TiC in Ni-Ti-C system was complex; several reactions were involved in the combustion synthesis of TiC-Ni composite. The Ni-Ti intermediate phases play important roles during the formation of TiC. Moreover, the influence of heating rate on the size range of $\mathrm{TiC}$ was also discussed.
\end{abstract}

Keywords: combustion synthesis; composite; TiC; Ni-Ti-C; formation mechanism; DTA

\section{Introduction}

Titanium carbide ceramic materials are attractive reinforcements utilized in metal matrix composites due to a unique combination of high melting temperature $\left(3200{ }^{\circ} \mathrm{C}\right)$, high hardness $(3200 \mathrm{HV})$, low density $\left(4.95 \mathrm{~g} / \mathrm{cm}^{-3}\right)$, good thermal and chemical stability, excellent wear resistance, and high fracture toughness [1]. The extremely high melting point of $\mathrm{TiC}$ made them essentially fabricated through powder consolidation technology. However, it is still difficult to prepare these materials from powders due to their strong covalent bonding and low self-diffusion coefficients even under high temperature and high pressure [2]. Recently, some special manufacturing technologies have been developed to consolidate them, such as self-propagating high-temperature synthesis (SHS) $[3,4]$, reactive hot pressing (RHP), spark plasma sintering (SPS) $[1,5]$ and transient plastic phase processing (TPPP). However, the energy- and time-intensive nature made them less practical to industry. It was also found that the ignition temperature in Ti-C mixture prepared under optimized high-energy ball milling (HEBM) conditions can be greatly decreased [6]. However, the synthesis process is complex, and further improvement is necessary for industrial application.

Compared with these special manufacturing processes, combustion synthesis [2,7] offered a technically simpler and economically more attractive route to fabricate the high-strength metal matrix 
composites due to a large cost-saving on the processing time, energy consumption, and high reaction purity [8]. Combustion synthesis is generally divided into two types: plane wave propagation ignited at one end of the sample and thermal explosion initiated by the uniform heating of the sample $[9,10]$. The latter is more attractive due to convenient operation [11]. The ignition temperature of pure TiC ceramic made by combustion synthesis from $\mathrm{Ti}$ and $\mathrm{C}$ powder blends was very high, close to the melting point of $\mathrm{Ti}\left(1678^{\circ} \mathrm{C}\right)$. The introduction of suitable metal powders (such as $\mathrm{Al}, \mathrm{Fe}, \mathrm{Cu}$ ) into Ti and $C$ mixed powders is a potential solution to reduce the energy consumption and material cost of titanium carbide ceramic materials, because it can enhance the density and simultaneously lower the ignition temperature through the formation of low melting point intermetallic compounds or the liquid phase from the reverse eutectic reaction [12-15]. Ni is also a promising candidate which can greatly decrease the synthesis temperature of $\mathrm{TiC}-\mathrm{Ni}$ composite and possesses a good wettability with $\mathrm{TiC}$. The influence of $\mathrm{C} / \mathrm{Ti}$ ratio [2] on the stoichiometry and morphology of $\mathrm{TiC}_{\mathrm{x}}$ has been investigated, and the mechanism of SHS of TiC-Ni cermet was studied by means of a combustion front quenching method [16]. However, the roles of Ni-Ti intermediate phases as well as the detailed reaction procedure during the combustion synthesis of $\mathrm{Ni}-\mathrm{Ti}-\mathrm{C}$ system need to be further revealed.

In this paper, the phase composition evolution of the $\mathrm{Ni}-\mathrm{Ti}-\mathrm{C}$ system and the roles of $\mathrm{Ni}-\mathrm{Ti}$ intermediate phases during combustion synthesis were studied to reveal the formation mechanism of TiC. The effect of heating rate and holding time on the microstructure of TiC-Ni composite was also investigated.

\section{Materials and Methods}

Commercial nickel powders (18 $\mu \mathrm{m}, 99.9 \%$ purity), titanium powders ( $38 \mu \mathrm{m}, 99.9 \%$ purity), and carbon powders $(1 \mu \mathrm{m}, 99.9 \%$ purity) were used as raw materials. The mass ratio of $\mathrm{Ni}$, $\mathrm{Ti}$, and $\mathrm{C}$ in the $20 \mathrm{wt} \% \mathrm{Ni}$-Ti-C powder mixture was 20:64:16 (the molar ratio of Ti/C was 1:1). The $20 \mathrm{wt} \% \mathrm{Ni}$-Ti-C powders were mechanically stirred in a Turbula mixer for $50 \mathrm{~min}$ to obtain a homogeneous powder mixture, and then the powder mixture was cold-pressed into a green body. The density of the green body was about $85 \%$ of theoretical density.

The exothermic and endothermic behaviors of $20 \mathrm{wt} \% \mathrm{Ni}-\mathrm{Ti}-\mathrm{C}$ green body were studied by differential thermal analysis (DTA), the green bodies were heated to $1200{ }^{\circ} \mathrm{C}$ at heating rates of $5{ }^{\circ} \mathrm{C} / \mathrm{min}, 20^{\circ} \mathrm{C} / \mathrm{min}, 40^{\circ} \mathrm{C} / \mathrm{min}$, and $80^{\circ} \mathrm{C} / \mathrm{min}$ in the DTA apparatus under argon atmosphere. To reveal the combustion synthesis mechanism of TiC-Ni composite, the green bodies were heated to different temperatures and then gas quenched; the temperature points were selected based on the DTA curve at a slow heating rate of $5{ }^{\circ} \mathrm{C} / \mathrm{min}$. The weight of the $20 \mathrm{wt} \% \mathrm{Ni}-\mathrm{Ti}-\mathrm{C}$ green body used for each DTA test was just $1 \mathrm{~g}$. After DTA test, the samples for microstructure analysis were cut from the sintered green bodies and then treated by grinding and polishing. The treated samples were investigated by using scanning electron microscopy (SEM, JEOL, Tokyo, Japan) together with energy dispersive spectrometry (EDS), and the phases were identified using X-ray diffraction (XRD, Philips X'pert, PANalytical B.V., Almelo, The Netherlands).

To further study the effect of high heating rate on the combustion synthesis of TiC-Ni composite, the green body of $200 \mathrm{~g}$ was heated to $1200{ }^{\circ} \mathrm{C}$ in a vacuum induction melting furnace and the heating rate was higher than $200{ }^{\circ} \mathrm{C} / \mathrm{min}$. The sample was kept at $1200^{\circ} \mathrm{C}$ in the vacuum induction melting furnace for a certain holding time $(15 \mathrm{~min})$ in the furnace after combustion synthesis to investigate the effect of holding time on the microstructure of samples.

\section{Results and Discussion}

\subsection{Synthesis Mechanism}

To investigate the combustion synthesis mechanism of $20 \mathrm{wt} \% \mathrm{Ni}-\mathrm{Ti}-\mathrm{C}$ system, the green bodies were heated to $1200^{\circ} \mathrm{C}$ at different heating rates by using a DTA instrument under argon atmosphere. The DTA curves at heating rates of $5{ }^{\circ} \mathrm{C} / \mathrm{min}$ and $20^{\circ} \mathrm{C} / \mathrm{min}$ are shown in Figure 1 . The results 
indicated that there were two obvious exothermic peaks and one endothermic peak in both DTA tests, and the peak positions of each DTA curve were very close, though the heating rates were different. However, the higher heating rate of $20^{\circ} \mathrm{C} / \mathrm{min}$ resulted in a much more violent exothermic reaction due to the accumulation of the reaction heat which cannot be diffused timely during DTA test, exhibiting a stronger exothermic peak than that at lower heating rate. The XRD results of $20 \mathrm{wt} \%$ Ni-Ti-C green bodies which were heated to $1200{ }^{\circ} \mathrm{C}$ in the DTA instrument are shown in Figure 2 . The diffraction peaks indicated that the final reaction products were composed of $\mathrm{TiC}$ and $\mathrm{Ni}$ phases, though the heating rates were different, and no obvious Ni-Ti or Ni-Ti-C ternary phases were detected, which is consistent with Yang's results [17]. It can be concluded that the reaction mechanism of the $20 \mathrm{wt} \% \mathrm{Ni}$-Ti-C system should be the same, though two different heating rates were employed.

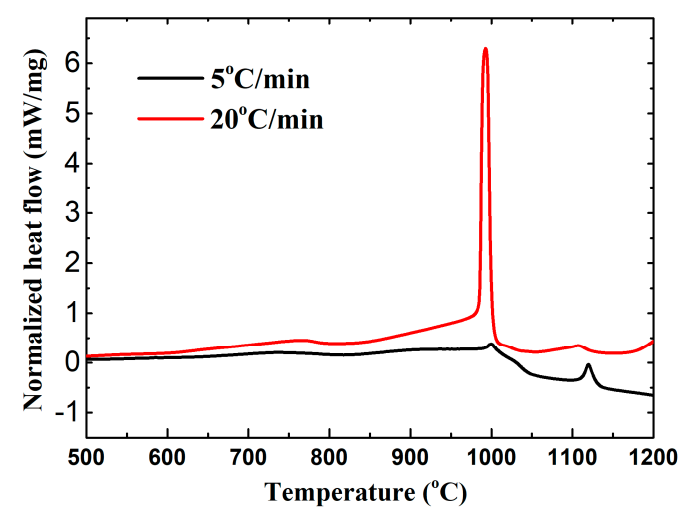

Figure 1. The differential thermal analysis (DTA) curves of $20 \mathrm{wt} \% \mathrm{Ni}$-Ti-C green bodies at heating rates of $5{ }^{\circ} \mathrm{C} / \mathrm{min}$ and $20^{\circ} \mathrm{C} / \mathrm{min}$.

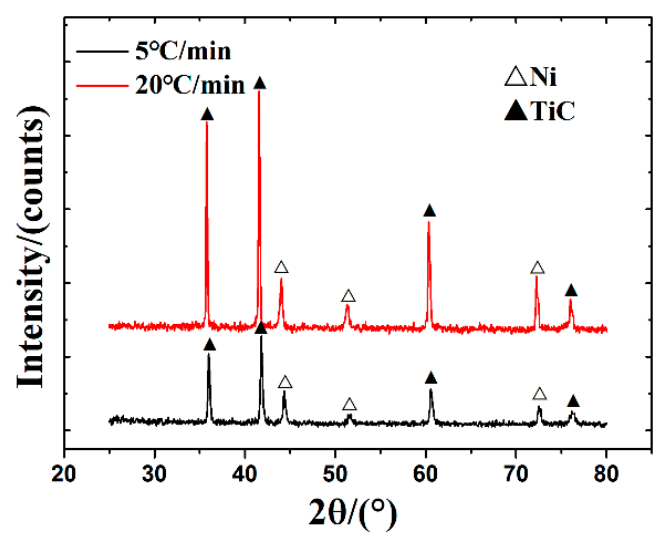

Figure 2. XRD patterns of the sintered green bodies after DTA tests (up to $1200^{\circ} \mathrm{C}$ ) at heating rates of $5^{\circ} \mathrm{C} / \mathrm{min}$ and $20^{\circ} \mathrm{C} / \mathrm{min}$.

The DTA curve at a slow heating rate of $5{ }^{\circ} \mathrm{C} / \mathrm{min}$ was used to analyze the change of heat flow during the combustion synthesis process, considering that the small endothermic peaks or exothermic peaks are usually covered by large peaks in the DTA curve and the details tend to be ignored when the fast heating rate is used. The exothermic peaks were found at $737^{\circ} \mathrm{C}, 900{ }^{\circ} \mathrm{C}, 1000{ }^{\circ} \mathrm{C}$, and $1120^{\circ} \mathrm{C}$, and one endothermic peak occurred at $1090^{\circ} \mathrm{C}$, as shown in Figure 3.

All the melting points of pure $\mathrm{Ni}\left(1684^{\circ} \mathrm{C}\right)$, $\mathrm{Ti}\left(1678{ }^{\circ} \mathrm{C}\right)$, and $\mathrm{C}\left(3500{ }^{\circ} \mathrm{C}\right)$ are higher than $1200{ }^{\circ} \mathrm{C}$, and the reaction temperature between $\mathrm{Ti}$ and $\mathrm{C}$ is also much higher than $1200^{\circ} \mathrm{C}$; therefore, it can be inferred that the peaks in this curve should be caused by the reaction between $\mathrm{Ni}$ and $\mathrm{Ti}$, or the reaction of $\mathrm{Ni}-\mathrm{Ti}-\mathrm{C}$ ternary system. It is reported that $\mathrm{TiC}$ and $\mathrm{Ni}$ are the final thermodynamically stable phases of the Ni-Ti-C system in the combustion synthesis (exothermic 
reaction: $\mathrm{Ti}+\mathrm{C}+x \mathrm{Ni} \rightarrow \mathrm{TiC}+x \mathrm{Ni}+\mathrm{Q}$ ) [2]. The quenching experiments were carried out to further reveal more details during the combustion synthesis process. The quenching temperatures were selected as $737^{\circ} \mathrm{C}, 900^{\circ} \mathrm{C}, 1000^{\circ} \mathrm{C}$, and $1120^{\circ} \mathrm{C}$, respectively, according to the peak positions in the DTA curve at a heating rate of $5{ }^{\circ} \mathrm{C} / \mathrm{min}$.

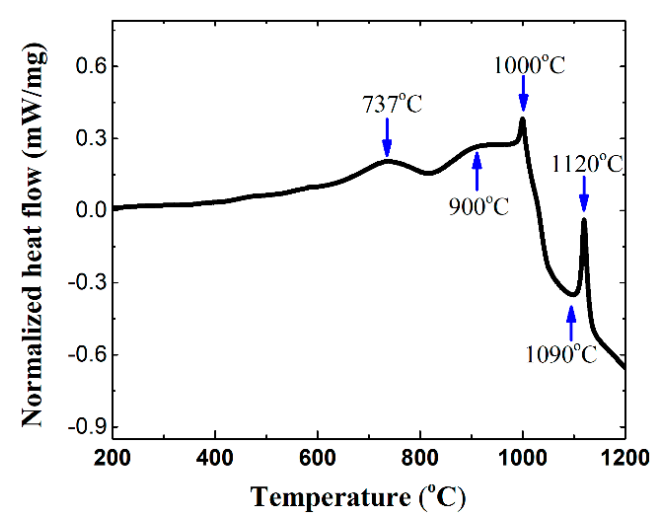

Figure 3. The details of DTA curve of $20 \mathrm{wt} \% \mathrm{Ni}-\mathrm{Ti}-\mathrm{C}$ green body at a heating rate of $5{ }^{\circ} \mathrm{C} / \mathrm{min}$.

Figure 4 shows the XRD patterns of the sintered green bodies which were heated to different temperatures and then quenched. The results indicated that a small amount of Ti-Ni intermetallic compounds $\left(\mathrm{Ti}_{2} \mathrm{Ni}\right.$ and $\left.\mathrm{Ni}_{3} \mathrm{Ti}\right)$ started to form, and the $\mathrm{Ni}$, $\mathrm{Ti}$, and $\mathrm{C}$ phases were still the main components in the sintered compact when the $20 \mathrm{wt} \% \mathrm{Ni}$-Ti-C green body was quenched at $737^{\circ} \mathrm{C}$. It can be inferred that the solid-state diffusion reaction started to occur in the contacting zone of Ti and $\mathrm{C}$ particles at this temperature, resulting in a locally compositional deviation of $\mathrm{Ti}$ or $\mathrm{Ni}$ [16]. Therefore, a very small amount of $\mathrm{Ti}_{2} \mathrm{Ni}$ and $\mathrm{Ni}_{3} \mathrm{Ti}$ were formed firstly, corresponding to a very mild exothermic peak in the DTA curve. The Ni-Ti intermetallic compounds were also observed in a Ti-C-25 $\mathrm{wt} \% \mathrm{Ni}$ reactant mixture using time-resolved X-ray diffraction [18].

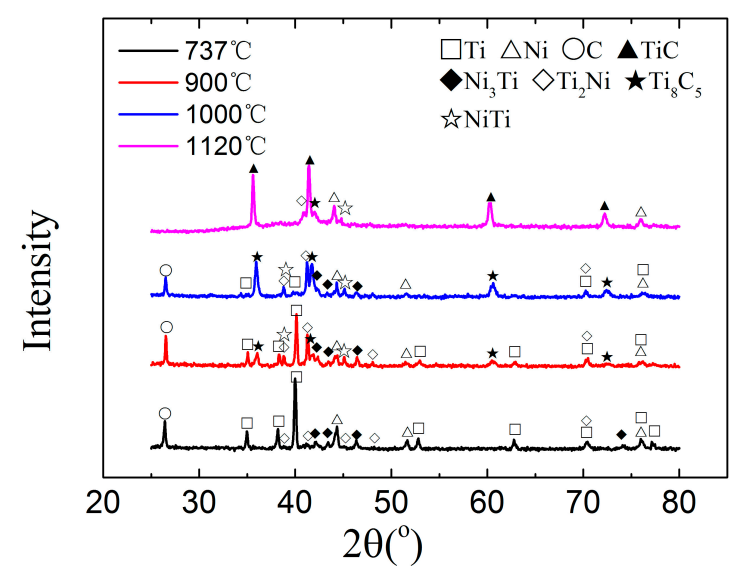

Figure 4. XRD patterns of sintered green bodies quenched at different temperatures with the heating rate of $5{ }^{\circ} \mathrm{C} / \mathrm{min}$.

The XRD pattern of the sintered green body quenched at $900{ }^{\circ} \mathrm{C}$ shows that the intensity of $\mathrm{Ti}_{2} \mathrm{Ni}$ and $\mathrm{Ni}_{3} \mathrm{Ti}$ diffraction peaks increased-especially for the $\mathrm{Ti}_{2} \mathrm{Ni}$ phase, which indicated that the weight ratio of $\mathrm{Ti}_{2} \mathrm{Ni}$ increased. Meanwhile, the content of $\mathrm{Ni}$ and Ti phases in the sintered green body decreased. Compared with the sintered green body quenched at $737^{\circ} \mathrm{C}$, a small amount of $\mathrm{Ti}_{8} \mathrm{C}_{5}$ and NiTi phases were detected in the combustion-synthesized products quenched at $900{ }^{\circ} \mathrm{C}$. Thus, it is suggested that a few reactions took place predominantly in the temperature range of $737-900{ }^{\circ} \mathrm{C}$. 
Ti reacted with $\mathrm{Ni}$ to form $\mathrm{Ti}_{2} \mathrm{Ni}$, $\mathrm{NiTi}$, and $\mathrm{Ni}_{3} \mathrm{Ti}$, resulting in a significant increase of Ti-Ni intermetallic compounds. In addition, the formation of non-stoichiometric $\mathrm{Ti}_{8} \mathrm{C}_{5}$ could be inferred as a result of reaction between $\mathrm{C}$ and $\mathrm{Ti}-\mathrm{Ni}$ intermetallic compounds, considering that the ignition temperature of pure $\mathrm{TiC}$ ceramic made by combustion synthesis from Ti and $\mathrm{C}$ powder blends was very high. The formation of $\mathrm{Ti}_{8} \mathrm{C}_{5}$ during the combustion synthesis of the Ni-Ti-C system has barely been reported in previous research work.

Compared with the XRD pattern of the combustion-synthesized products quenched at $900{ }^{\circ} \mathrm{C}$, the synthesized products quenched at $1000{ }^{\circ} \mathrm{C}$ showed a similar phase composition; $\mathrm{Ti}_{2} \mathrm{Ni}, \mathrm{Ni}_{3} \mathrm{Ti}_{1}, \mathrm{NiTi}$, and $\mathrm{Ti}_{8} \mathrm{C}_{5}$ were the main reaction products. Changes in the intensity of the diffraction peaks in XRD patterns indicated a large increase in the amount of $\mathrm{Ti}_{8} \mathrm{C}_{5}$, which can be attributed to a substantial formation of $\mathrm{Ti}_{8} \mathrm{C}_{5}$ caused by the reaction between $\mathrm{C}$ and Ti-Ni intermetallic compounds, benefiting from the formation of a great deal of Ni-Ti intermediate phases in the temperature range of $900-1000^{\circ} \mathrm{C}$. However, the observable intensities of diffraction peaks for $\mathrm{Ti}_{2} \mathrm{Ni}$ and $\mathrm{Ni}_{3} \mathrm{Ti}$ in the quenched samples at $900{ }^{\circ} \mathrm{C}$ and $1000{ }^{\circ} \mathrm{C}$ was similar, implying that there was a balance between the formation and consumption of Ti-Ni intermetallic compounds.

The DTA curve of the $20 \mathrm{wt} \%$ Ni-Ti-C system in Figure 3 also shows a sharp endothermic peak around the temperature of $1090^{\circ} \mathrm{C}$. There exists a eutectic point between $\mathrm{Ti}_{2} \mathrm{Ni}$ and $\mathrm{Ti}$ at the temperature of $942{ }^{\circ} \mathrm{C}$ according to the Ni-Ti binary phase diagram [19]. However, the composition deviation of $\mathrm{Ni}$ or Ti in the initial Ti-Ni liquid solution and an extremely short diffusion time contributed to a lag of eutectic temperature compared with the theoretical eutectic temperature. Thus, the endothermic peak around $1090^{\circ} \mathrm{C}$ could be deduced as the endothermic transition $\mathrm{Ti}_{2} \mathrm{Ni}+\mathrm{Ti} \rightarrow \mathrm{Ni}-\mathrm{Ti}$ liquid solution .

The Ni-Ti liquid solution provided an excellent channel for the diffusion and transport of elements; a Ni-Ti-C ternary liquid solution formed along with $\mathrm{C}$ particles dissolving into the Ni-Ti liquid phase, the TiC particles precipitated subsequently from Ni-Ti-C liquid solution as the solution was saturated [3]. Meanwhile, $\mathrm{Ti}_{8} \mathrm{C}_{5}$ turned into stoichiometric $\mathrm{TiC}$ by the convenient supplement of carbon atoms in the Ni-Ti-C liquid phase. Consequently, $\mathrm{TiC}$ and $\mathrm{Ni}$ were the predominant phases detected in the XRD pattern of sintered green body quenched at $1120^{\circ} \mathrm{C}$. A small amount of intermediate phases remained in the sintered green body after quenching test at $1120^{\circ} \mathrm{C}$, indicating an incompleteness of the combustion synthesis at this stage. There should be a small amount of pure Ti and pure $\mathrm{C}$ remaining in the sintered green body according to the $\mathrm{Ti} / \mathrm{C}$ ratio in raw material and the reaction process described above. The diffraction peaks of pure Ti and pure $\mathrm{C}$ were not found in the XRD pattern due to a very small amount of Ti and C.

As the temperature continued to rise above $1120^{\circ} \mathrm{C}$, the DTA curve showed an endothermic reaction peak corresponding to the formation of $\mathrm{Ni}$-Ti liquid solution from a reverse eutectic reaction between $\mathrm{NiTi}$ and $\mathrm{Ni}_{3} \mathrm{Ti}$ according to the $\mathrm{Ni}$-Ti binary phase diagram (theoretical eutectic temperature is $1118{ }^{\circ} \mathrm{C}$ [20]). Then, the newly formed Ni-Ti liquid solution, the remaining Ni-Ti intermediate phases, $\mathrm{Ti}_{8} \mathrm{C}_{5}$, and the remaining few pure $\mathrm{Ti}$ and pure $\mathrm{C}$ finally transformed to $\mathrm{Ni}$ and $\mathrm{TiC}$ following the reactions described before.

\subsection{Microstructure}

The TiC-20 wt \%Ni composite can be prepared by combustion synthesis using a $20 \mathrm{wt} \% \mathrm{Ni}$-Ti-C powder system, and the morphology of TiC-Ni composites synthesized in DTA instrument at different heating rates are shown Figure 5. The spherical micron-scale TiC particles were uniformly distributed in a nearly continuous Ni matrix. The size of spherical TiC particles increased with the increasing of heating rate; the $\mathrm{TiC}$ size range varied from $<1 \mu \mathrm{m}$ to $2-5 \mu \mathrm{m}$ when the heating rate was increased from $5{ }^{\circ} \mathrm{C} / \mathrm{min}$ to $80^{\circ} \mathrm{C} / \mathrm{min}$. The coarsening of TiC particles can be explained as follows: A higher heating rate led to a faster heat accumulation, including the input of an external heat source and the exothermic reaction of combustion synthesis once ignited. Simultaneously, the rapid rise in temperature resulted in a very violent reaction, resulting in a greater number of Ni-Ti liquid phases which can provide a more efficient diffusion channel for $\mathrm{C}$ atoms. Consequently, the growth-driving force of $\mathrm{TiC}$ was 
reduced, and the precipitation of $\mathrm{TiC}$ from the saturated solution and the grain coarsening of $\mathrm{TiC}$ particles became much easier.
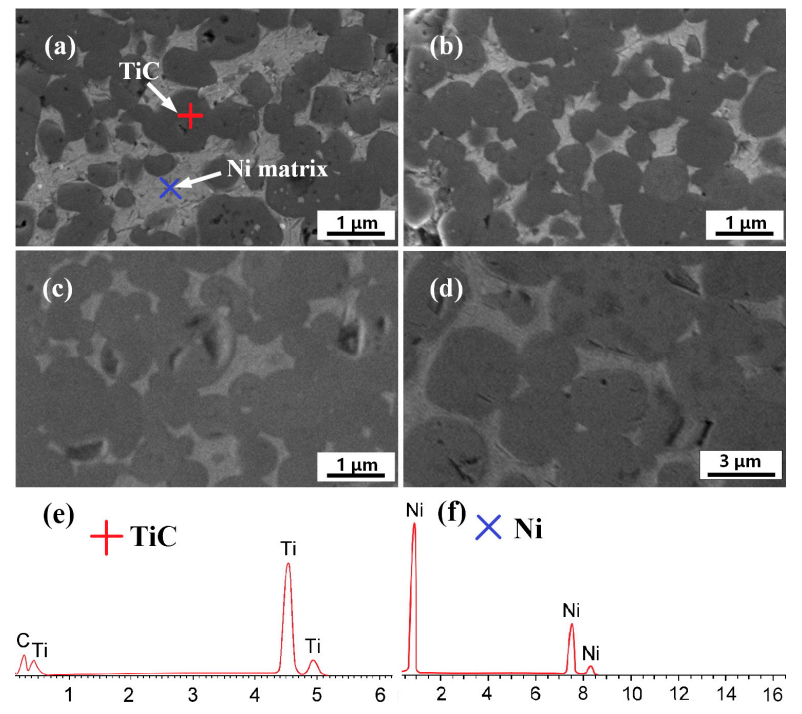

Figure 5. SEM micrographs of sintered green bodies in DTA instrument with different heating rates: (a) $5{ }^{\circ} \mathrm{C} / \mathrm{min}$; (b) $20^{\circ} \mathrm{C} / \mathrm{min}$; (c) $40{ }^{\circ} \mathrm{C} / \mathrm{min}$; and (d) $80{ }^{\circ} \mathrm{C} / \mathrm{min}$; (e,f) The energy-dispersive spectrometry (EDS) spectra of $\mathrm{TiC}$ and $\mathrm{Ni}$, respectively.

The larger-size samples ( $200 \mathrm{~g})$ were fabricated by combustion synthesis in a vacuum induction melting furnace with a heating rate $\left(>200^{\circ} \mathrm{C} / \mathrm{min}\right)$ to investigate the preparation feasibility of large-size $\mathrm{TiC}-20 \mathrm{wt} \% \mathrm{Ni}$ for industrial application. Figure 6 shows the XRD patterns of samples without soaking and with soaking for $15 \mathrm{~min}$ in vacuum induction melting furnace at $1200{ }^{\circ} \mathrm{C}$. Phase composition analysis indicated that the combustion synthesis reaction was completed in the vacuum induction melting furnace. $\mathrm{TiC}$ and $\mathrm{Ni}$ phases were the final reaction products, and no intermetallic compounds were detected. The SEM micrographs of the sintered green bodies by using a vacuum induction melting furnace are shown in Figure 7. The size of TiC particles slightly increased after soaking. The TiC size range prepared in the DTA instrument at a heating rate of $80^{\circ} \mathrm{C} / \mathrm{min}$ was about $2-5 \mu \mathrm{m}$, and the size range of $\mathrm{TiC}$ prepared in the vacuum induction melting furnace without soaking was slightly increased to 3-10 $\mu \mathrm{m}$. This indicated that the influence of heating rate increase on the TiC size is not significant when the heating rate is greater than $80^{\circ} \mathrm{C} / \mathrm{min}$.

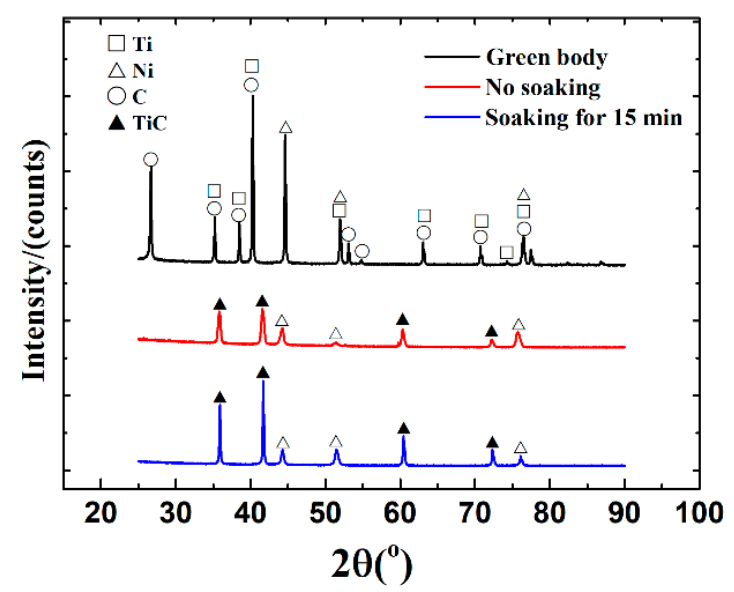

Figure 6. XRD patterns of the original green body, and the sintered green bodies with and without soaking for $15 \mathrm{~min}$ at $1200^{\circ} \mathrm{C}$ in a vacuum induction melting furnace. 

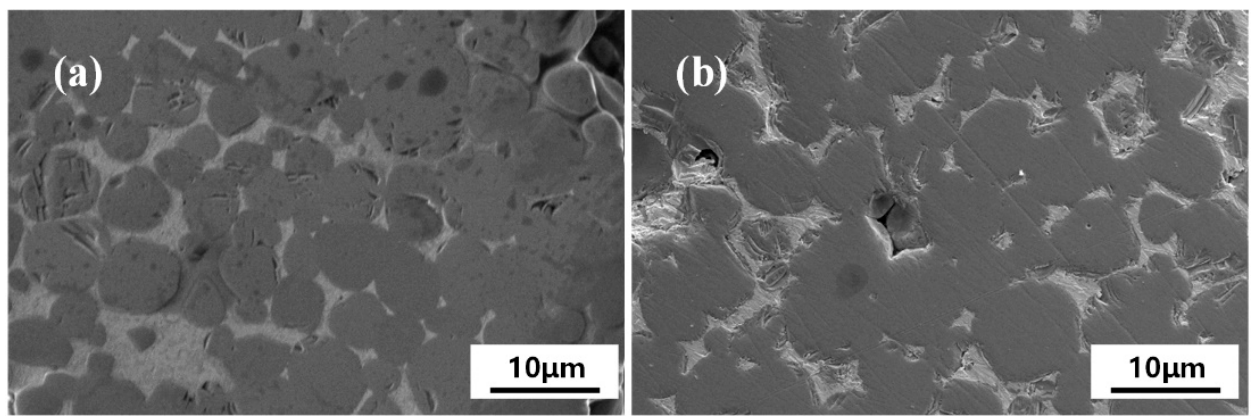

Figure 7. SEM micrographs of the sintered green bodies in a vacuum induction melting furnace. (a) No soaking and (b) soaking at $1200{ }^{\circ} \mathrm{C}$ for $15 \mathrm{~min}$.

\section{Conclusions}

The TiC-20 wt \%Ni composite can be prepared by combustion synthesis using a $20 \mathrm{wt} \% \mathrm{Ni}$-Ti-C powder system. The combustion synthesis mechanism could be concluded as follows: Firstly, $\mathrm{Ti}_{2} \mathrm{Ni}$ and $\mathrm{Ni}_{3} \mathrm{Ti}$ were formed through solid-state diffusion reactions between $\mathrm{Ni}$ and $\mathrm{Ti}$ at the initial stage of combustion synthesis under low temperature. In the temperature range of $737-900{ }^{\circ} \mathrm{C}, \mathrm{Ti}_{2} \mathrm{Ni}$, $\mathrm{Ni}_{3} \mathrm{Ti}$, and $\mathrm{NiTi}$ were formed due to a higher rate of solid-state diffusion reactions between $\mathrm{Ni}$ and $\mathrm{Ti}$, meanwhile the non-stoichiometric $\mathrm{Ti}_{8} \mathrm{C}_{5}$ was formed through the reaction between $\mathrm{C}$ and Ti-Ni intermetallic compounds. With a further increase in temperature, the $\mathrm{Ni}$-Ti liquid phase began to form due to the reverse eutectic reaction between $\mathrm{Ti}_{2} \mathrm{Ni}$ and $\mathrm{Ti}$, then $\mathrm{C}$ particles dissolved into $\mathrm{Ni}$-Ti liquid solution to form $\mathrm{Ni}-\mathrm{Ti}-\mathrm{C}$ liquid solution, and $\mathrm{TiC}$ particles precipitated subsequently from the saturated liquid solution. Meanwhile, $\mathrm{Ti}_{8} \mathrm{C}_{5}$ turned into stoichiometric $\mathrm{TiC}$ by the convenient supplement of carbon atoms in the Ni-Ti-C liquid phase.

During the combustion synthesis of the $20 \mathrm{wt} \% \mathrm{Ni}-\mathrm{Ti}-\mathrm{C}$ powder system, the size of spherical TiC particles increased with the increasing of heating rate; the TiC size range varied from $<1 \mu \mathrm{m}$ to $2-5 \mu \mathrm{m}$ when the heating rate was increased from $5{ }^{\circ} \mathrm{C} / \mathrm{min}$ to $80^{\circ} \mathrm{C} / \mathrm{min}$. However, the influence of heating rate increase on the $\mathrm{TiC}$ size was not significant when the heating rate was greater than $80^{\circ} \mathrm{C} / \mathrm{min}$.

Acknowledgments: This work was financially supported by the Joint fund of the Ministry of Education of China under Project No. 6141A02022210, the National Natural Science Foundation of China under Project No. 51704195, the Industry-University-Research Cooperation Annual Plan of Shanghai under Project No. CXY-2016-004 and the National Industrial Basis Improvement Project under Project No. TC160A310-12.

Author Contributions: All authors contributed to the study design, data analysis, and discussion, as well as to the writing and editing of the manuscript. Study conception and design: Guoliang Zhu, Anping Dong, Da Shu and Baode Sun; experimental work: Wei Wang, Rui Wang and Weitao Pan; data analysis and discussion: Guoliang Zhu, Chuanbao Zhao, Donghong Wang, Haijun Huang, Dafan Du, Da Shu, Sheng Jiang and Yilong Pu; and manuscript writing, editing and revision: Guoliang Zhu, Wei Wang and Chuanbao Zhao.

Conflicts of Interest: The authors declare no conflict of interest.

\section{References}

1. Tjong, S.C.; Ma, Z.Y. Microstructural and mechanical characteristics of in situ metal matrix composites. Mater. Sci. Eng. R 2000, 29, 49-113. [CrossRef]

2. Yang, Y.F.; Jin, S.B.; Jiang, Q.C. Effect of reactant C/Ti ratio on the stoichiometry, morphology of $\mathrm{TiC}_{\mathrm{x}}$ and mechanical properties of $\mathrm{TiC}_{\mathrm{x}}-\mathrm{Ni}$ composite. CrystEngComm 2013, 15, 852-855. [CrossRef]

3. Yang, Y.F.; Wang, H.Y.; Liang, Y.H.; Zhao, R.Y.; Jiang, Q.C. Fabrication of steel matrix composites locally reinforced with different ratios of $\mathrm{TiC} / \mathrm{TiB}_{2}$ particulates using $\mathrm{SHS}$ reactions of $\mathrm{Ni}-\mathrm{Ti}-\mathrm{B}_{4} \mathrm{C}$ and Ni-Ti- $\mathrm{B}_{4} \mathrm{C}-\mathrm{C}$ systems during casting. Mater. Sci. Eng. A 2007, 445-446, 398-404. [CrossRef]

4. Azadmehr, A.; Taheri-nassaj, E. An in situ (W,Ti)C-Ni composite fabricated by SHS method. J. Non-Cryst. Solids 2008, 354, 3225-3234. [CrossRef] 
5. Zohari, S.; Sadeghian, Z.; Lotfi, B.; Broeckmann, C. Application of spark plasma sintering (SPS) for the fabrication of in situ Ni-TiC nanocomposite clad layer. J. Alloys Compd. 2015, 633, 479-483. [CrossRef]

6. Manukyan, K.V.; Lin, Y.C.; Rouvimov, S.; McGinn, P.J.; Mukasyan, A.S. Microstructure-reactivity relationship of $\mathrm{Ti}+\mathrm{C}$ reactive nanomaterials. J. Appl. Phys. 2013, 113, 024302. [CrossRef]

7. Huang, X.; Yin, C.; Zhao, Z.; Zhang, L.; Wu, J. Microstructures and Toughening of TiC-TiB $2 \mathrm{Ceramic}^{-}$ Composites with Cr-Based Alloy Phase Prepared by Combustion Synthesis in High-Gravity Field. Adv. Mater. Sci. Eng. 2015, 2015, 358746. [CrossRef]

8. Gotman, I.; Travitzky, N.A.; Gutmanas, E.Y. Dense in situ $\mathrm{TiB}_{2} / \mathrm{TiN}$ and $\mathrm{TiB}_{2} / \mathrm{TiC}$ ceramic matrix composites: Reactive synthesis and properties. Mater. Sci. Eng. A 1998, 244, 127-137. [CrossRef]

9. Dunmead, S.D.; Readey, D.W.; Semler, C.E.; Hol, J.B. Kinetics of combustion synthesis in the Ti-C and Ti-C-Ni systems. J. Am. Ceram. Soc. 1989, 72, 2318-2324. [CrossRef]

10. Lasalvia, J.C.; Kim, D.K.; Lipsett, R.A.; Meyers, M.A. Combustion synthesis in the Ti-C-Ni-Mo system: Part I. Micromechanisms. Metall. Mater. Trans. A 1995, 26, 3001-3009. [CrossRef]

11. Klinger, L.; Gotman, I.; Horvitz, D. In situ processing of $\mathrm{TiB}_{2} / \mathrm{TiC}$ ceramic composites by thermal explosion under pressure: Experimental study and modeling. Mater. Sci. Eng. A 2001, 302, 92-99. [CrossRef]

12. Yang, Y.F.; Wang, H.Y.; Liang, Y.H.; Zhao, R.Y.; Jiang, Q.C. Effect of nickel addition on the exothermic reaction of titanium and boron carbide. J. Mater. Res. 2007, 22, 169-174. [CrossRef]

13. Saidia, A.; Chrysanthou, A.; Wood, J.V.; Kellie, J.L.F. Preparation of Fe-TiC composites by the thermal-explosion mode of combustion synthesis. Ceram. Int. 1997, 23, 185-189. [CrossRef]

14. Zarrinfar, N.; Shipway, P.; Kennedy, A.; Saidi, A. Carbide stoichiometry in $\mathrm{TiC}_{\mathrm{x}}$ and $\mathrm{Cu}-\mathrm{TiC}_{\mathrm{x}}$ produced by self-propagating high-temperature synthesis. Scr. Mater. 2002, 46, 121-126. [CrossRef]

15. Li, Y.X.; Hu, J.D.; Wang, H.Y.; Guo, Z.X.; Chumakov, A.N. Thermodynamic and lattice parameter calculation of $\mathrm{TiC}_{\mathrm{x}}$ produced from $\mathrm{Al}-\mathrm{Ti}-\mathrm{C}$ powders by laser igniting self-propagating high-temperature synthesis. Mater. Sci. Eng. A 2007, 458, 235-239. [CrossRef]

16. Xiao, G.; Fan, Q.; Gu, M.; Wang, Z.; Jin, Z. Dissolution-precipitation mechanism of self-propagating high-temperature synthesis of TiC-Ni cermet. Mater. Sci. Eng. A 2004, 382, 132-140. [CrossRef]

17. Yang, Y.F.; Wang, H.Y.; Zhao, R.Y.; Liang, Y.H.; Zhan, L.; Jiang, Q.C. Effects of C particle size on the ignition and combustion characteristics of the SHS reaction in the $20 \mathrm{wt} \% \mathrm{Ni-Ti-C}$ system. J. Alloys Compd. 2008, 460, 276-282. [CrossRef]

18. Wong, J.; Larson, E.M.; Holt, J.B.; Waide, P.A.; Rupp, B.; Frahm, R. Time-resolved X-ray diffraction study of solid combustion Reactions. Science 1990, 249, 1406-1409. [CrossRef] [PubMed]

19. Baker, H.; Okamoto, H. ASM Handbook (Vol. 3): Alloy Phase Diagram; ASM International: Geauga County, $\mathrm{OH}, \mathrm{USA}, 1992 ;$ ISBN 9780871703811.

20. Backerud, L.; Carlsson, B.; Oskarsson, R.; Mikus, M. Study of the Ni-Rich and Co-Rich Corners of the Systems Ni-Ti-C and Co-Ti-C. Scand. J. Metall. 1974, 3, 225-235.

(c) 2017 by the authors. Licensee MDPI, Basel, Switzerland. This article is an open access article distributed under the terms and conditions of the Creative Commons Attribution (CC BY) license (http:/ / creativecommons.org/licenses/by/4.0/). 